\title{
ORGANIC HOMEMADE SOAP MAKING WORKSHOP AT RPTRA MERUYA SELATAN, WEST JAKARTA
}

\author{
Zulfa Fitri Ikatrinasari, Igna Saffrina Fahin, Diah Utami \\ Universitas Mercu Buana Jakarta, Indonesia.
}

\begin{abstract}
One of DKI Jakarta's government programs is the development of a Child Friendly Integrated Public Space (RPTRA), where every urban village in DKI Jakarta will be built RPTRA. One of the urban villages in DKI Jakarta that the RPTRA is building and the leading program of the PKK activator is already running is the Meruya Selatan village. The PKK group in South Meruya Village is one of the groups of women who have played a role in improving the family's economy. Several home industry businesses have been carried out by the PKK Group in South Meruya Village, namely the food and handicraft industry. Besides food and crafts, PKK Mart RPTRA Meruya Selatan also needs to develop new superior products that have prospective market prospects. Among the products that have interesting prospects to be developed are organic homemade soap. For this reason, training was made in making organic homemade soap to increase insight and knowledge in the diversification of business products to the community around the South Meruya RPTRA, PKK Women, and Youth Organization in Meruya Selatan Village.
\end{abstract}

Keywords: Organic Homemade Soap, Child-Friendly Integrated Public Spaces (RPTRA), Home Industry.

\section{INTRODUCTION}

One of DKI Jakarta's government programs is the development of a Child Friendly Integrated Public Space (RPTRA), where every urban village in DKI Jakarta will be built RPTRA. RPTRA Built in order to provide a child-friendly integrated public space equipped with physical facilities, it functions as a means of providing services and activities especially for children and residents, so that the RPTRA becomes a place for children's growth and development, a place for citizens' social activities, as well as adding green open spaces and places for water absorption soil. The RPTRA is a center for learning, training, development and referrals from various activity groups (POKTAN). The RPTRA program and activities are integrated with 10 main PKK programs which are essentially basic human needs including children, including: (1) appreciation and practice of Pancasila, (2) mutual cooperation, (3) food, (4) clothing, (5) clothing ) housing and household management, (6) education and skills, (7) health, (8) development of cooperative life (9) environmental preservation and (10) healthy living planning.

One of the urban villages in DKI Jakarta that the RPTRA is building and the leading program of the PKK activator is already running is the Meruya Selatan village. The PKK group in South Meruya Village is one of the groups of women who have played a role in improving the family's economy. Several home industry businesses have been carried out by the PKK Group in South Meruya Village, namely the food and handicraft industry.

Besides food and crafts, PKK Mart RPTRA Meruya Selatan also needs to develop new superior products that have prospective market prospects. Among the products that have interesting prospects to be developed are organic homemade soap. The organic homemade soap business business opportunity has never been done by the South Meruya South Jakarta RPTRA even though the prospects are very good. The business of organic homemade soap can be done by PKK ladies and Karang Taruna Kelurahan Meruya Selatan because the process of producing organic homemade soap is not difficult to do.

Soap is defined as a product that is produced from the reaction process of saponification or neutralization of fatty acids, oils, waxes and resins with certain organic bases such as ammonia or amines (ammonia derivatives such as triethanolamine) or inorganic bases.

The characteristics of a soap are strongly influenced by the characteristics of the oil used. Each oil also has a dominant type of fatty acid. These fatty acids will determine the characteristics of the soap produced. The method of making soap can be done in three ways namely cold process, hot process and organic soap (glycerin soap). The techniques for making soap by cold process and hot process are generally the same in terms of the use of ingredients and the mixing process. The difference lies in the drying process (curing process), if the cold process requires curing time for 4-6 weeks, whereas by hot process soap can be used immediately after leaving the mold. 
The quality of the resulting soap product is influenced by several factors, first the composition of the different triglycerides in each oil used for the raw material for making soap. Triglyceride composition affects the level of hardness and solubility parameters of soap to water. The type of fatty acid is also very influential on the nature of the soap produced such as lauric acid (C12:0) and myristic acid which can provide hardening, cleaning and producing soft foam. Unlike the types of linoleic fatty acids (C18: 2) and oleic acids (C18: 1) which provide moisturizing properties on soap, while for the types of palmitic acid, ricinoleic and stearic (C18: 0) provide hardening and stabilizing foam properties.

Broadly speaking, the ingredients for making soap consist of basic ingredients and additives. The basic ingredients are solvents or other basic materials so that they generally occupy a greater volume than other materials. Additional ingredients are materials that function to provide certain effects desired by consumers (Wasitaatmadja 1997). Things that must be considered in formulating soap include good foaming characteristics, does not irritate the eyes, mucous membranes and skin, has optimal cleansing power and does not provide effects that can damage the skin and has a fresh and attractive odor (Fahmitasari 2004).

Bath soap products have developed into a primary need in the community, utilized by all walks of life every day. The soap industry is competing to create innovative and useful bath soap products, varying in terms of shape, color and aroma. Currently, natural-based bath soap products are still limited on the market. Most still use synthetic ingredients as active ingredients. This synthetic active ingredient has a negative effect on human skin, because it has the potential to cause me irritation to consumers who have sensitive skin. Examples of synthetic active ingredients that are harmful to human skin and are highlighted today are diethanolamine (DEA), Sodium Lauryl Sulfate (SLS), and triclosan that is found in almost all health soap on the market. Based on research results, if triclosan accumulates in fat in the human body, it will potentially cause thyroid dysfunction. Therefore, at this time many manufacturers of bath soap are starting to look to natural ingredients to be used as substitutes for active ingredients for making health soaps. The purpose of using natural ingredients is of course to eliminate synthetic materials, such as dyes, perfumes, bleach, antibacterial, and others.

The potential market for oorganic homemade soap products is quite prospective, especially in urban environments because of its attractive characteristics, especially with its natural properties that will provide added value to the resulting soap products. Unfortunately, currently the PKK ladies in South Meruya village do not have the knowledge and skills in the production of organic homemade soap and the quality requirements for organic soap.

Based on the above conditions, training in making organic homemade soap is done to increase insight and knowledge in the diversification of business products to the community around the South Meruya RPTRA, PKK Ladies, and Youth Groups in Meruya Selatan Village.

\section{METHOD OF ACTIVITIES}

The method of activities that will be used in providing insight and skills in the production of organic homemade soap to the South Meruya RPTRA Manager, PKK Women of Meruya Selatan Village, and Karang Taruna of Meruya Selatan Village, West Jakarta are as follows:

1) Varied Lectures and Question and Answer Discussion

This method was chosen to convey concepts that are important to be understood and mastered by trainees. The use of this method with the consideration that the lecture method combined with audio and video can provide relatively much material in a compact, fast and easy. The material provided is the production of homemade organic soap and organic homemade soap quality test.

\section{2) Demonstration}

This method was chosen to show a work process, namely the stages of producing organic homemade soap and the quality test of organic homemade soap. The demonstration was carried out by the instructor in front of the participants and then the participants were divided into four groups given the opportunity to produce organic homemade soap.

\section{3) Exercise}

This method is used to provide an opportunity for each participant in designing a good and qualified Organic Homemadet Soap Production Manual.

Soap Making Method

1. Cold Process Method:

- Mixing of oil + alkali at a temperature of 35 - 40 degrees Celsius until trace \& thicken

- Insert the mold for 24 hours 
- Cut pieces

- Curing (drying): 2-4 weeks

2. Hot Process Method

- After mixing, warm up 1-3 hours

- Cuting 1-2 weeks

- Produces liquid soap, organic soap \& cream soap

3. Melt \& Pour Method

- Soap base (almost finished soap) is melted and mixed with additional ingredients (fragrance, coloring, etc.)

\section{RESULTS}

\section{Profile of Citizenship Partners}

The dominant occupation of residents in Meruya Selantan Urban Village is private employees with a proportion between 15 percent and 30 percent of the total population. The number of housewives without formal employment is also quite large with a proportion of 13 percent to 18 percent. Housewives who live in Kelurahan. The dominant occupants of Meruya Selatan Kelurahan are housewives, namely 86 percent, who have entrepreneurs only 9 percent, while the rest also work as teachers and private employees with the same percentage of 3 percent.

Family earners are dominated by those who earn less than Rp. 3.5,000,000 per month or maximum is equal to the minimum wage of DKI Jakarta Province. Number of residents who earn less than Rp. 2,000,000 per month is still quite large at 31 percent, only 6 percent of prospective partner partners with an income of more than Rp. $5,000,000$ per month.

The dominant number of housewives in South Meruya Kelurahan have done food entrepreneurship activities. To improve business skills and opportunities for housewives in South Meruya, training in making organic homemade soap is conducted. Thus this activity is expected to be an alternative to improve the family's business and economy.

\section{Implementation of Activities}

Tools and materials

- Containers or pans

- Stick blender or hand mixer

- Plastic or wooden spoons

- Scales

- Print

- Oil

- Alkali $(\mathrm{NaOH})$

- Water

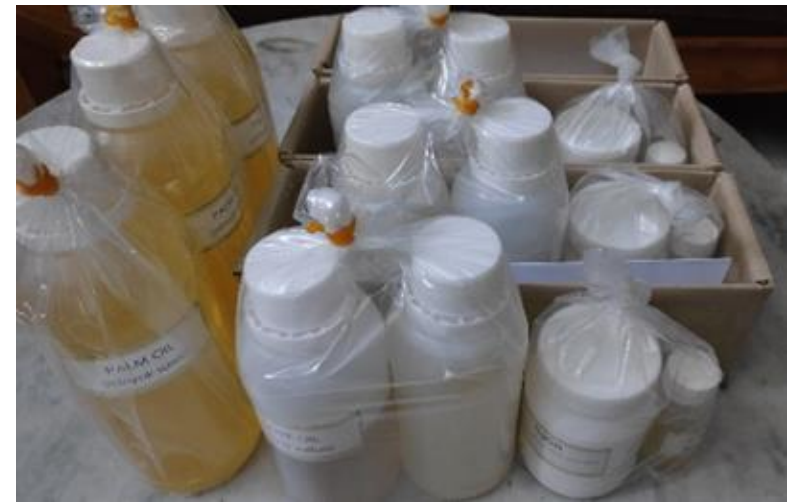

Figure 1. Basic ingredients for making soap

Basic soap bath recipe

- 150 gr $(30 \%)$ - Coconut Oil

- 150 gr (30\%) - Palm Oil

- 200 gr (40\%) - Olive Oil (Pomace Olive Oil)

- 145 gr - Water (Deionized / Demineralized / Distilled Water)

- $72.5 \mathrm{gr}-\mathrm{NaOH}$ 


\section{Stages of the process of making soap}

The steps to make soap with a cold method are as follows:

1. Prepare all tools and materials

2. Pour water into containers according to size.

3. Take $\mathrm{NaOH}$ in a separate place and weigh according to the recipe size. Carefully put $\mathrm{NaOH}$ into the water little by little, there will be an immediate reaction of boiling water and a pungent vapor (a normal reaction).

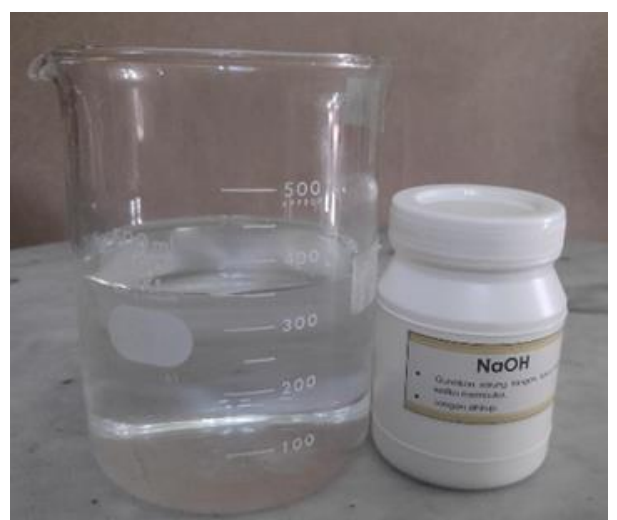

Figure 2. Stages of dissolving $\mathrm{NaOH}$ with water

4. Stir until all the $\mathrm{NaOH}$ dissolves. Leave it for a while until the solution reaches a temperature below $40^{\circ} \mathrm{C}$. * Always put $\mathrm{NaOH}$ in water, not vice versa. If you enter the reverse will give the effect of a volcano erupting. Dangerous!

5. While waiting for the $\mathrm{NaOH}$ solution to cool. Weigh according to size and mix the oil into the container provided. * If the coconut oil / palm oil clot, melt it first. If there is nothing to clot it does not need to be heated.

6. When the temperature of the $\mathrm{NaOH}$ solution has reached around $30-35^{\circ} \mathrm{C}$, pour into the oil slowly.

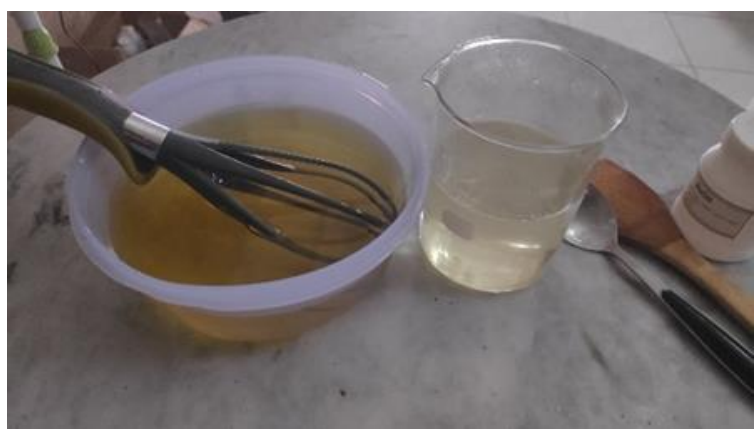

Figure 4. Mix $\mathrm{NaOH}$ solution with oil

7. Stir continuously using a mixer or hand mixer until completely mixed (trace). When the soap mixture has reached the trace, stop stirring. Prepare molds that have been coated in plastic or paper.

8. Pour into the mold, don't forget to collect the remnants on the edge of the pan using a spatula.

9. Cover using used cloth or used towel on top of the mold. To keep it hot and continue the saponification process. Place it in a safe place out of reach of children and leave it for 1-2 days.

10. Then remove the soap from the mold. Cut to the desired size. Store in a dry place with a good air flow, allow 2-4 weeks.

\section{DISCUSSION}

After conducting the training the participants can understand the process of making homemade organic soap, how to manage the production process that is environmentally friendly, how to produce efficient products and how to market them. This can be seen from the results of the questionnaire given to participants who have an 
average value of all questions is 4.25 . This value shows the participants were satisfied with this activity. The recapitulation of the results of the questionnaire given to participants can be seen in Table 1.

Table 1. Recapitulation of questionnaire results

\begin{tabular}{crrrrrr}
\hline Question. & 1 & 2 & 3 & 4 & 5 & 6 \\
\hline 1 & 4 & 5 & 5 & 4 & 4 & 4 \\
2 & 5 & 5 & 4 & 4 & 4 & 4 \\
3 & 4 & 5 & 5 & 4 & 5 & 5 \\
4 & 3 & 5 & 5 & 5 & 5 & 5 \\
5 & 4 & 4 & 4 & 4 & 4 & 4 \\
6 & 4 & 5 & 5 & 4 & 4 & 4 \\
7 & 5 & 5 & 5 & 5 & 5 & 5 \\
8 & 4 & 5 & 4 & 4 & 5 & 4 \\
9 & 4 & 4 & 4 & 4 & 3 & 4 \\
10 & 5 & 4 & 5 & 4 & 4 & 4 \\
11 & 4 & 4 & 4 & 4 & 4 & 4 \\
12 & 4 & 5 & 3 & 4 & 4 & 4 \\
13 & 4 & 4 & 4 & 4 & 4 & 4 \\
14 & 4 & 4 & 4 & 4 & 4 & 4 \\
15 & 4 & 4 & 4 & 4 & 4 & 4 \\
16 & 4 & 4 & 4 & 3 & 3 & 4 \\
17 & 4 & 5 & 5 & 5 & 5 & 4 \\
18 & 4 & 4 & 4 & 5 & 4 & 5 \\
\hline Average & 4.11 & 4.50 & 4.33 & 4.17 & 4.17 & 4.22 \\
\hline
\end{tabular}

Questions on the questionnaire are *:

1. I have never received this training material

2. The material presented is very useful for me

3. The material presented is able to motivate entrepreneurship

4. The message of this material is very clear and understandable

5. Submission of this material is very interesting

6 . The time provided in the delivery of this material is sufficient

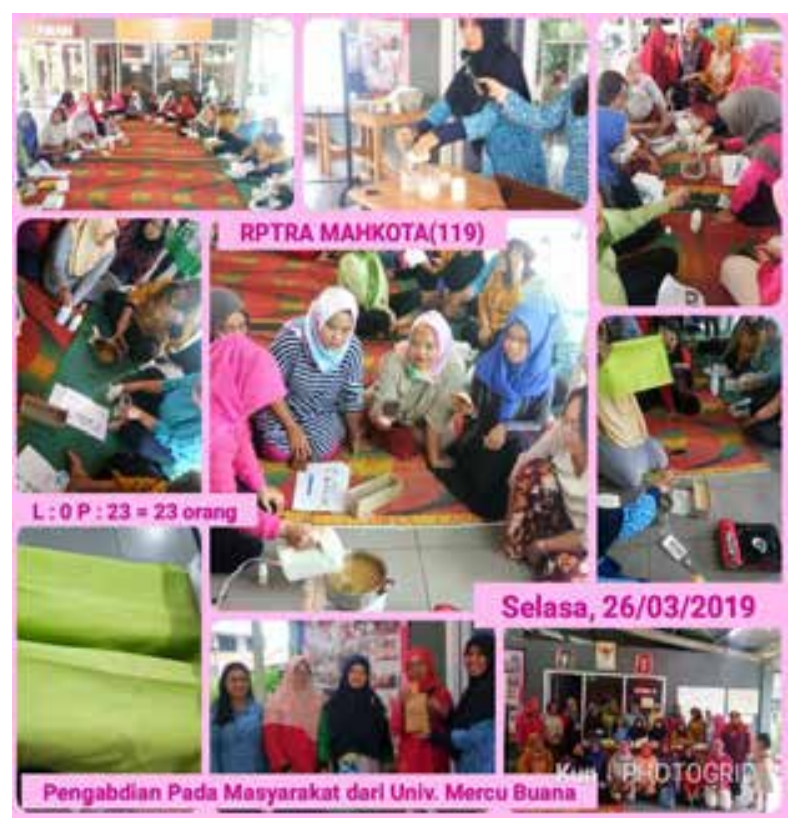

Figure 5. The implementation of organic homemade soap making workshop 
From the results of the questionnaire, it is known that the first question has the lowest value, which is 4.11. This is because there are participants who have received the material. While the second question has the highest value because the material presented is very useful for participants. The material presented also motivated participants to become entrepreneurs, this can be seen from the value of the questionnaire which was 4.33 . The graph of the results of the questionnaire can be seen in Figure 6.

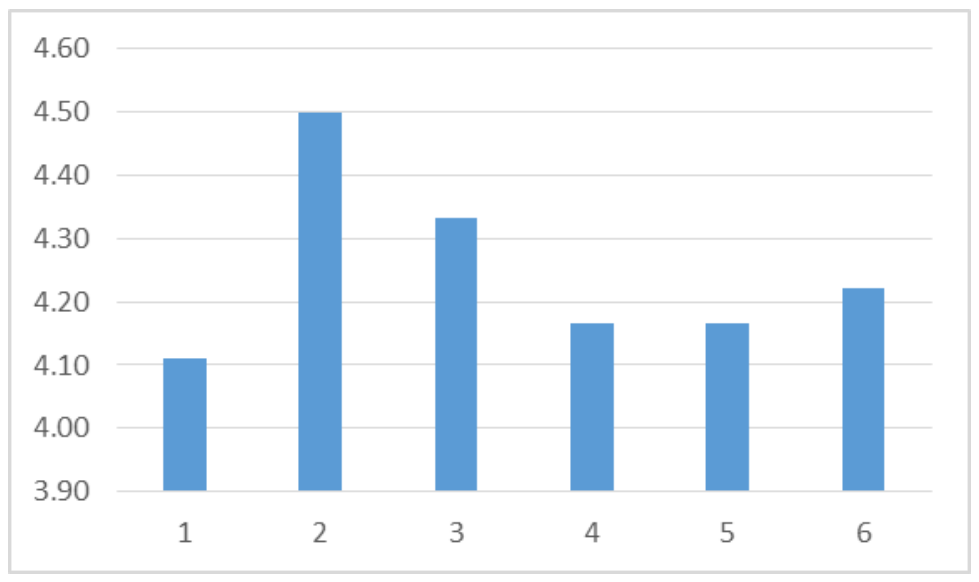

Figure 6. Recapitulation of questionnaire results

\section{CONCLUSIONS}

The service has been carried out well and received a positive response from the community. The extension activities were greatly appreciated by the local community because it was hoped that the extension with the theme "Training of Organic Homemade Soap Production Processes in South Meruya Village" would be able to increase the participants' knowledge and skills in developing their businesses.Each paper must be at first inserted abstract with total amount of 200-300 words followed to keywords. The abstract must be written in English. It has to be the summarized statement on the problem, approach, results and conclusion of the work the author had made. The abstract content includes background, purpose, method application, results and conclusion.

\section{REFERENCES}

Ibrahim B, Suptijah P, Amin H. 2010. Penggunaan Kitosan Sebagai Pengisi Dalam Pembuatan Sabun Organic. Jurnal Pengolahan Hasil Perikanan Indonesia, XIII(1), 14-23.

Naomi, P., Lumban Gaol, A.M. \& Toha, M.Y.. 2013. Pembuatan Sabun Lunak Dari Minyak Goreng Bekas Ditinjau Dari Kinetika Reaksi Kimia. Jurnal Teknik Kimia UNSRI. 19(2), 42-48.

Permono, A. 2015. Membuat Sabun \& Shampo. Jakarta: Penebar Swadaya.

Sari, T.I., Kasih, J.P. \& Sari, TJ.N. 2010. Pembuatan Sabun Padat Dan Sabun Cair Dari Minyak Jarak. Jurnal Teknik Kimia UNSRI. 17(1), 28-33.

Sukawaty, Y., Warnida, H. \& Artha, A.V. 2016. Formulasi Sediaan Sabun Mandi Padat Ekstrak Etanol Umbi Bawang TiwaI (Eleutherine bulbosa (Mill.) Urb. Media Farmasi, 13(1), 14-22.

Zulkifli, M., Teti Estiasih, T. 2014. Sabun dari Distilat Asam Lemak Minyak Sawit - Zulkifli, dkk Jurnal Pangan dan Agroindustri, 2(4), 170-177. 